\title{
Overexpression of cysteine protease in transgenic Brassica rapa enhances resistance to bacterial soft rot and up-regulate the expression of various stress-regulated genes
}

\author{
Yu-Jin Jung • Kang Kwon-Kyoo
}

Received: 3 September 2010 / Accepted: 6 September 2010

(C) Korean Society for Plant Biotechnology

\begin{abstract}
Cysteine proteases have been known as a critical factor in plant defense mechanisms in pineapple, papaya, or wild fig. Papain or ficin is one kind of cysteine proteases that shows toxic effects to herbivorous insects and pathogenic bacteria. However, resistance to bacterial soft rot of plants genetically engineered with cysteine protease has been little examined thus far. We cloned a cysteine protease cDNA from Ananas comosus and introduced the gene into Chinese cabbage (Brassica rapa) under the control of the cauliflower mosaic virus $35 \mathrm{~S}$ promoter. The transgene was stably integrated and actively transcribed in transgenic plants. In comparisons with wild-type plants, the $T_{2}$ and $T_{3}$ transgenic plants exhibited a significant increase in endo-protease activity in leaves and enhanced resistance to bacterial soft rot. A cDNA microarray analysis revealed that several genes were more abundantly transcribed in the transgenic than in the wild type. These genes encode a glyoxal oxidase, PR-1 protein, PDF1, protein kinase, LTP protein, UBA protein and protease inhibitor. These results suggest an important role for cysteine protease as a signaling regulator in biotic stress signaling pathways, leading to the build-up of defense mechanism to pathogenic bacteria in plants.
\end{abstract}

Keywords Brassica rapa, Cysteine protease, Microarray analysis, Soft rot resistance, Transgenic plant

Y.-J. Jung • K. K.-Kyoo ( $ه)$

Institute of Genetic Engineering, Hankyong National

University, Ansung, 456-749, Korea

e-mail: kykang@hknu.ac.kr

K. K.-Kyoo

Department of Horticulture, Hankyong National University, Ansung, 456-749, Korea

\section{Introduction}

Cysteine proteases are involved in a variety of proteolytic functions in higher plants (Granell et al. 1998). A number of genes encoding papain-like cysteine proteases have been isolated from leaves (Lohman et al. 1994; Ueda et al. 2000; Gepstein et al. 2003), flowers (Eason et al. 2002), legume nodules (Kardailsky and Brewin 1996), fruit (Muta et al. 1997) and germinating seeds (Ling et al. 2003). Some cysteine proteases have specific characteristics such as a C-terminal KDEL motif. This motif, which is an endoplasmic reticulum retention signal for soluble proteins, allows cysteine protease propeptides to be stored either in a special organelle, called the ricinosome (Schmid et al. 1999), or in KDEL vesicles (KV) before transport to vacuoles through a Golgi complexindependent route (Okamoto et al. 2003).

Cysteine protease expression has been intensively studied with various expression patterns reported for different stages of plant development (Buchanan-Wollaston and Ainsworth 1997; Guerrero et al. 1998; Xu and Chye 1999). Such proteases are involved in processing and degradation of seed storage proteins (Shimada et al. 1994; Toyooka et al. 2000), fruit ripening (Alonso and Granell 1995) as well as in legume nodule development (Naito et al. 2000). They are also implicated in responses to stresses such as wounding, cold, and drought (Schaffer and Fischer 1988; Koizumi et al. 1993; Linthorst et al. 1993; Harrak et al. 2001) as well as in programmed cell death, reproduction, senescence and pathogenesis (Xu and Chye 1999; Solomon et al. 1999; Schmid et al. 1999).

D' Silva et al. (1988) demonstrated that the cleavage of poly (ADP-ribose) polymerase (PARP) by cysteine proteases was activated during the hypersensitive response of cowpea to cowpea rust fungus. PARP is normally a target for cleavage by caspases during apoptosis in animals (Vaux and 
Korsmeyer 1999). Inhibition of cysteine proteases with cystatin blocked programmed cell death in soybean triggered by either oxidative stress or an avirulent strain of Pseudomonas syringae pv. glycinea (Solomon et al. 1999). Both Solomon et al. (1999) and D' Silva et al. (1988) have suggested a regulatory role for cysteine proteases and their inhibitors during the hypersensitive response in plants.

In this paper, we transformed Chinese cabbage (Brassica rapa) with a $B A A 1$ gene encoding cysteine protease from pineapple fruit, with the purpose of comparing the resistance of bacterial soft rot between the transgenic plants and the wild-type (WT) counterpart. Patterns of gene expression in leaves were also compared by microarray analysis.

\section{Materials and methods}

Construction of transformation vectors

The cDNA encoding cysteine protease was isolated from the pineapple fruit (designated as $B A A 1$ ) and digested with $X h o \mathrm{I}$ and $K p n I$ to contain the open reading frame thereof. The $X b a \mathrm{I}-K p n \mathrm{I}$ fragment was cloned between the $X b a \mathrm{I}$ and $K p n \mathrm{I}$ sites of a binary vector $\mathrm{pBI} 121-\mathrm{Hm}$, which contained the CaMV 35S promoter. The binary vector is a derivative of pBI121 (Clontech) and contains two antibiotic resistance genes, i.e., neomycin phosphotransferase II gene and hygromycin phosphotransferase gene.

\section{Transformation of Chinese cabbage (Brassica rapa)}

The vector containing the sense $35 S: B A A 1$ construct was transferred from Escherichia coli JM109 into Agrobacterium tumefaciens via tri-parental mating with an E. coli strain containing a mobilization plasmid, pRH021. The pBI121-Hm vector containing the sense $35 \mathrm{~S}: B A A 1$ construct was transferred into Agrobacterium LBA4404 strain and transferred to Chinese cabbage (OSOME ecotype) by the Agrobacterium method (He 1990). Transgenic seedlings were selected in terms of resistance to both kanamycin and hygromycin in a selection medium. The medium consisted of a full-strength MS medium (Murashige and Skoog 1962), supplemented with $10 \mathrm{~g} \mathrm{liter}^{-1}$ sucrose, $0.1 \mathrm{~g} \mathrm{liter}^{-1}$ myoinositol, $0.5 \mathrm{~g} \mathrm{liter}^{-1}$ MES, $500 \mathrm{mg}$ liter $^{-1}$ carbenicillin, $200 \mathrm{mg} \mathrm{liter}^{-1}$ Claforan (Hoechst), $50 \mathrm{mg}$ liter $^{-1}$ kanamycin and $40 \mathrm{mg} \mathrm{liter}^{-1}$ hygromycin. After adjusting the $\mathrm{pH}$ to 5.7 with $\mathrm{KOH}$, the medium was solidified with $0.5 \%$ (w/v) Gelan gum (Sigma). The transgenic $T_{2}$ and $T_{3}$ plants from independently derived transgenic lines were used in this study.
RT-PCR and realtime PCR analysis

Total RNA was isolated using TRIzol method (Invitrogen). In all cases, RNA was treated with RNase free DNase and the DNase was removed according to the instructions of the supplier (AMBION). The RNA was quantified in a spectrophotometer at $260 \mathrm{~nm}$. Approximately $5 \mu \mathrm{g}$ of total RNA was reverse transcribed using random hexamers (Amersham Pharmacia Biotech Inc) and reverse transcriptase without RNaseH activity (Fermentas) in a final volume of $20 \mu \mathrm{L} .2 .5$ $\times 10^{5}$ copies of GeneAmplimer pAW 109 RNA (Applied Biosystem) were added to the reverse transcription reaction. The cDNA was diluted 50 times and $5 \mu \mathrm{L}$ was used for amplification by PCR in a volume of $25 \mu \mathrm{L}$. BAA1 genespecific primers were used (BAA-F: 5'-ATGGCTTCCA AAGTTCAACTCGTG-3') and (BAA-R: 5'-TCAAGTTT CAGAAACCATCTT-3'). The constitutively expressed actin gene (ACT-F: 5'- ATGGTTGGGATGGGTCAAAAA -3' and ACR-R: 5'- ACGGAGCTCGTTGT AGAAAGT -3') was used as an internal control of RNA quantity and GeneAmplimer pAW 109 RNA (109-F: 5'-CATGTCAAA TTTCACTGCCTTCATC-3' and 109-R: 5'-TGACCACCC AGCCATCCTT-3') as positive control of the RT-PCR efficiency. Primer sequences used for confirm microarray analyses were showed Table 1 . In order to get semi-quantitative results, the number of cycles of the PCR reactions was adjusted for each gene to obtain barely visible bands in agarose gels. Aliquots of the PCR reaction were loaded on agarose gels and stained with ethidium bromide.

For real-time quantitative PCR experiments (RT-qPCR), the cDNAs were diluted 100 times, $B A A 1$ and actin target genes were amplified using gene specific primers designed from the coding sequence using the Primer Express 1.5 software (Applied Biosystems). The primer pairs for $B A A 1$ were 5'CTCTATCGGAGCAAGAAGTTCTCG-3' and 5'- GCCAC ACCGTTGTTAGATATG ATG -3' and for actin 5'- ATGG TTGGGATGGGTCAAAAA -3' and 5'- ACGGAGCTCG TTGTAGAAAGT -3'. Both primers pairs amplified $115 \mathrm{bp}$ amplicons with similar melting temperatures (ca. $81^{\circ} \mathrm{C}$ ). Samples were amplified using a SmartCycler II (Takara) detector in conjunction with the Quantitect SYBR green PCR kit (Qiagen $\mathrm{GmbH}$ ). Thermal cycling conditions were 15 min denaturation at $95^{\circ} \mathrm{C}$ followed by 40 cycles $(15 \mathrm{sec}$ at $95^{\circ} \mathrm{C}, 30 \mathrm{sec}$ at $58^{\circ} \mathrm{C}, 30 \mathrm{sec}$ at $72^{\circ} \mathrm{C}$ ). Relative expression levels were calculated and the primers validated using the $\triangle \triangle \mathrm{CT}$ method (http://www.appliedbiosystems.com) using data obtained with the actin-specific primers as an internal control. 
Table 1 Gene-specific PCR primers for semiquantitative RT-PCR amplification

\begin{tabular}{|c|c|c|c|}
\hline Gene ID & Accession No. ${ }^{a}$ & Primer pair & Amplicon size \\
\hline At1g20760 & T42644 & $\begin{array}{l}\text { F: GGAGCAAGGAGGTAGTGCAG } \\
\text { R: TCCCAATCTTCATCCCAAAC }\end{array}$ & 218 \\
\hline At5g19580 & NM12196 & $\begin{array}{l}\text { F: CGATGGAAGACGGAGATGAT } \\
\text { R: GGGCTTGAGCTGTCTGAAAC }\end{array}$ & 279 \\
\hline At4g25780 & NM118710 & $\begin{array}{l}\text { F: TGCGTGGATTGGAGAGTACA } \\
\text { R: TGCCAGGAGGGAAATAGTTG }\end{array}$ & 272 \\
\hline At1g75830 & NM126274 & $\begin{array}{l}\text { F: TTTCTTTGCTGCTCTTGAAGC } \\
\text { R: GTTGCAAGATCCATGTCGTG }\end{array}$ & 334 \\
\hline At2g40560 & NM129618 & $\begin{array}{l}\text { F: TTGTGG ACGAGTCTTCGTTG } \\
\text { R: AAGCTTGTTTGAGGCTTGGA }\end{array}$ & 191 \\
\hline At5g56540 & AK117330 & $\begin{array}{l}\text { F: GGAGGCAATGAAGATGAAGC } \\
\text { R: GAAGAAT CCAAAGGCCATCA }\end{array}$ & 261 \\
\hline At5g47970 & NM124171 & $\begin{array}{l}\text { F: ATGGTTTGCTGAGAGGGATG } \\
\text { R: GGAGCAGCACTAAACCAAGG }\end{array}$ & 132 \\
\hline At2g18840 & NM127440 & $\begin{array}{l}\text { F: ATG GTTTGCTGAGAGGGATG } \\
\text { R: GGAGCAGCACTAAACCAAGG }\end{array}$ & 202 \\
\hline At5g38195 & NM123180 & $\begin{array}{l}\text { F: AAGAAGGCATGAAGGAAGCA } \\
\text { R: CCC AAGAGTTTGACCACGTT }\end{array}$ & 309 \\
\hline At4g12730 & NM117342 & $\begin{array}{l}\text { F: ATCATGCTAAC GCCAGAACC } \\
\text { R: GGGGCATTTAAGTTTGCTGA }\end{array}$ & 305 \\
\hline At2g38870 & NM124955 & $\begin{array}{l}\text { F: GCTTACGGGAACAAATGGTG } \\
\text { R: GACGACGATACGGTTTCCAT }\end{array}$ & 309 \\
\hline At1g63730 & DQ527168 & $\begin{array}{l}\text { F: TTTTGCATTCAGCCCCTTAC } \\
\text { R: TGCCAAGTTGAAGTGAGTCG }\end{array}$ & 183 \\
\hline At3g54620 & AY054645 & $\begin{array}{l}\text { F: AAAACA AGCTCAAGGCTCCA } \\
\text { R: CTGCGTCTCCATCAAGATCA }\end{array}$ & 242 \\
\hline At5g12120 & NM121250 & $\begin{array}{l}\text { F: GCAAAGTCCCTTCTGTGCTC } \\
\text { R: TTGGTTT TCGGATTCTCCAC }\end{array}$ & 258 \\
\hline At5g44420 & NM123810 & $\begin{array}{l}\text { F: CACCCTTATCTTCGCTGCTC } \\
\text { R: GTTGCATGATCCATGTTTGG }\end{array}$ & 186 \\
\hline At1g64160 & NM118500 & $\begin{array}{l}\text { F: TTTCAAATTCGGGAAACTCG } \\
\text { R: CCCTCCGACAACAGACAAAT }\end{array}$ & 150 \\
\hline At1g66270 & NM105298 & $\begin{array}{l}\text { F: AACTTGGGACCACAGATTCG } \\
\text { R: CCATCTTGCCATTCGAAGTT }\end{array}$ & 180 \\
\hline At5g21105 & NM001161257 & $\begin{array}{l}\text { F: AACAAACTC ACCACCGAAGG } \\
\text { R: CCTTTAGCCACGTCCACAAT }\end{array}$ & 258 \\
\hline At3g07080 & ВТ008641 & $\begin{array}{l}\text { F: GAGAAGGCTGTTTTGCTTGG } \\
\text { R: AACTCGC ATCCTTGTCCAAC }\end{array}$ & 324 \\
\hline At4g12530 & NM117323 & $\begin{array}{l}\text { F: GCTATGAGGCCTTGTTGCTC } \\
\text { R: CATCAGGAAGGGTACCTCCA }\end{array}$ & 237 \\
\hline
\end{tabular}

\footnotetext{
${ }^{a}$ The nucleotide sequences used for designing the primers are shown by their accession number. The designed primer pairs yielded a strong single band for each gene
}

Immunoblot analysis

Rosette leaves (about $0.2 \mathrm{~g} \mathrm{FW)} \mathrm{were} \mathrm{homogenized} \mathrm{with} \mathrm{a}$ Polytron in $1 \mathrm{~mL}$ of ice-chilled buffer containing $10 \mathrm{mM}$ Tris- $\mathrm{HCl}$ (pH 8.0), $2 \mathrm{mM}$ DTT and $0.2 \mathrm{mM}$ p-mercuribenzoate. The homogenate was centrifuged at $27,000 \mathrm{x}$ g for 20 min at $4^{\circ} \mathrm{C}$. Proteins in the supernatant were quantified as described by Bradford (1976) with bovine serum albumin as the standard. Proteins were separated by SDS-polyacrylamide gel electrophoresis using a Ready gel J gel (Bio-Rad) by the method described by Laemmli (1970), and electroblotted onto polyvinylidene difluoride membranes (Sequiblot PVDF membrane, Bio-Rad). Membranes were incubated with a $B A A 1$ antibody raised in rabbit against a peptide 
corresponding to the 14 amino acids (CSYVRSNDESMKYA) of the BAAl C-terminus. Immunoreactive proteins were detected with a second antibody, goat anti-rabbit $\operatorname{IgG}(\mathrm{H}+\mathrm{L})$ (Human IgG Adsorbed) horseradish peroxidase (Bio-Rad).

\section{Protease activity assay}

The assessment of total protease activity of Chinese cabbage leaves was carried out according to the method of Holwerda and Rogers (1992). In brief, $50 \mu \mathrm{L}$ leaf extract was mixed with $300 \mu \mathrm{L} 100 \mathrm{mM}$ sodium acetate buffer ( $\mathrm{pH}$ 5.0) or $300 \mu \mathrm{L} 100 \mathrm{mM}$ sodium phosphate buffer ( $\mathrm{pH}$ 7.0) containing $50 \mu \mathrm{L} 0.6 \%$ (w/v) azocasein (Sigma), supplemented with $100 \mu \mathrm{L} 0.1 \%$ Brij, and the mixture was incubated at 3 $0^{\circ} \mathrm{C}$ for $3 \mathrm{~h}$. The reaction was terminated by adding $200 \mu \mathrm{L}$ $10 \%$ TCA, filtered and the absorbance of the filtrate at 366 nm was determined (HITACHI U-2001 spectrophotometer). One unit of protease activity was defined as the enzyme amount that gives 0.01 absorbance increase per min.

Inoculation of soft rot bacteria and resistance evaluation

Ren's (2001) method was used for inoculation of Pectobacterium carotovorum ssp. obtained from the Korean Agricultural Culture Collection (KACC, http:mgd.niast.go.kr), National Institute of Agricultural Science \& Technology, RDA, Suwon, Korea. The bacteria for inoculation were freshly grown on NA agar medium ( $5 \mathrm{~g}$ of peptone, $3 \mathrm{~g}$ of beef extract, $2 \mathrm{~g}$ of yeast extract, and $15 \mathrm{~g}$ of Bacto-agar per liter) at $28^{\circ} \mathrm{C}$. Sterile water $(\mathrm{mL})$ was added to each plate and freshly-cultivated bacteria were scaped gently from the agar medium with a sterile glass rod. After centrifugation at 5,000 $\mathrm{xg}$, the bacterial pellet was resuspended in sterile water and adjusted to $\mathrm{OD}_{600}=0.2\left(2.5 \times 10^{8} \mathrm{CFU} / \mathrm{mL}\right)$. The leaves and roots were inoculated with the bacterial suspension by syringe infiltration. The inoculated plants were then transferred to a growth chamber and incubated at $28^{\circ} \mathrm{C}$ under continuous light, checked for 12 to $96 \mathrm{~h}$ after inoculation. The control plants were treated similarly with sterile water.

\section{cDNA microarray analysis}

Total RNA was extracted from leaves with TRIZOL reagent (Life Technologies) according to the manufacturer's instructions and purified by passing through a RNeasy column (Qiagen). After checking the RNA quality by gel electrophoresis (Agilent Bioanalyzer, Agilent Technol.), $40 \mu \mathrm{g}$ of total RNA was reverse transcribed by using oligo dT12-18 primer and aminoallyl-dUTP. The synthesized cDNA was labeled by reaction with dye (NHS-ester Cy3 or Cy5;
Amersham Biosci.) according to the method described by Hughes et al. (2001). The labeled cDNA was applied to the DNA microarray (Arabidopsis microarray, Agilent Technol.) and hybridized at $60^{\circ} \mathrm{C}$ for $17 \mathrm{~h}$. After washing, the microarray was scanned on a ScanArray 5000 (GSI Lumonics) and the image was analyzed by using QuantArray software (GSI Lumonics). The signal intensity of each spot was calibrated by subtraction of the intensity of the negative control. In analyzing the data, genes with expression levels higher than 500 were taken into account, and the genes with signal intensity ratios in the transgenics vs. the WT above 2.0 and below 0.5 were considered that the expression was up- and down-regulated, respectively, in the transgenics.

\section{Results}

Analysis of the 35S:BAA1 plants

The BAAl gene encoding cysteine protease was isolated from pineapple fruit by RT-PCR using primers designed against the published sequence (GeneBank: GI2351106). We introduced the BAAl gene fused with the CaMV 35S promoter into Chinese cabbage (Fig. 1A). After Agrobacteriummediated transformation, transformants were selected for hygromycin resistance (50 mg/L hygromycin). Transformants started to build up callus after 10 days-culture in the induction medium, an amorphous mass of cells appeared from the callus during the late period of the second generation of the culture, and many multi-shoots appeared from the third generation of the culture. After culture in the regeneration medium until the length of the plantlets reached $7-8 \mathrm{~cm}$, the organisms were induced to form roots (Fig. 1B). The rooted individuals were transferred to the pot to induce flowering by treatment at $8-10^{\circ} \mathrm{C}$ for 40 days. The flowered individuals were bud pollinated to produce $\mathrm{T}_{1}$. The $35 \mathrm{~S}: B A A 1$ transgenic $\mathrm{T}_{2}$ and $\mathrm{T}_{3}$ lines form the basis of this study. The $\mathrm{T}_{2}$ seeds were sown in the antibiotics-containing agar medium to eliminate non-transgenic individuals, while the homogeneous $\mathrm{T}_{3}$ seeds were sown in soil. Total RNA and watersoluble proteins were extracted from rosette leaves of the WT and several $T_{2}$ transgenic plants grown in an agar medium for 4 weeks under control conditions as described in Materials and Methods. RT-PCR and realtime PCR analysis showed that a signal corresponding to $B A A l$ was detected in the transgenic lines, while no signal was detectable in the WT (Fig. 2A). Protein gel blot hybridization with polyclonal antibody raised against $B A A 1$ showed that a band with a molecular mass between 36 and $50 \mathrm{kDa}$ was detected that corresponded, in terms of molecular mass, to sweet potato 
(A)

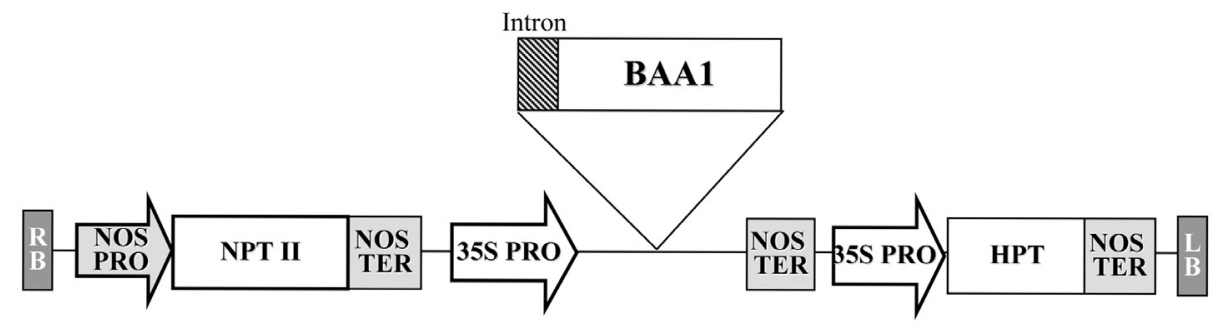

(B)
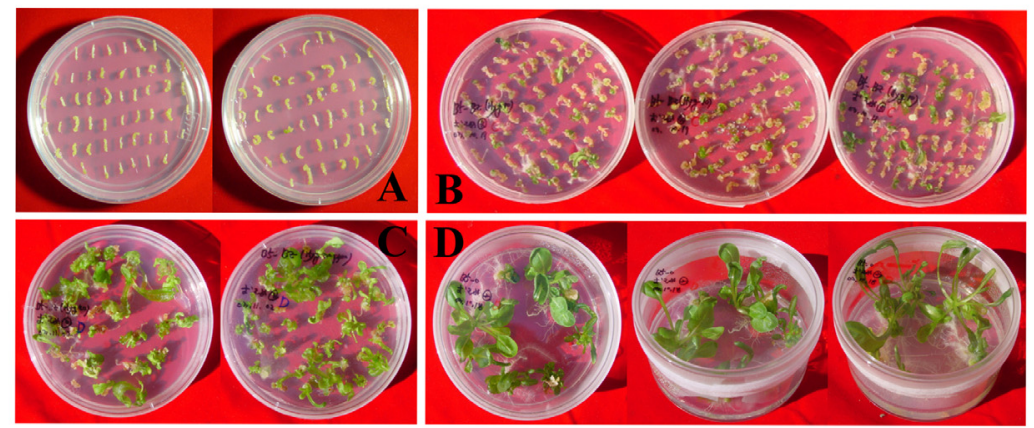

Fig. 1 Vector construction and transformation. (A); Binary plant expression vector pIG $121 \mathrm{Hm}$ for the expression of BAA1. Nos-p, nos gene promoter; HPT, hygromycin phosphotransferase gene; Nos-t, nos gene terminator; 35S-p, Cauliflower mosaic virus 35S- promoter; BAA1; LB, left border; RB, right border. (B); Plant transformation was used to hypocotyles of B. rapa by Agrobateium method (Material and Methods)

(A)

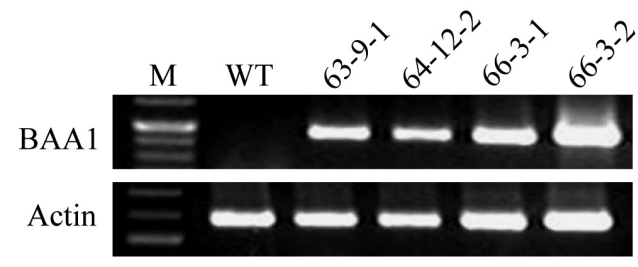

(B)

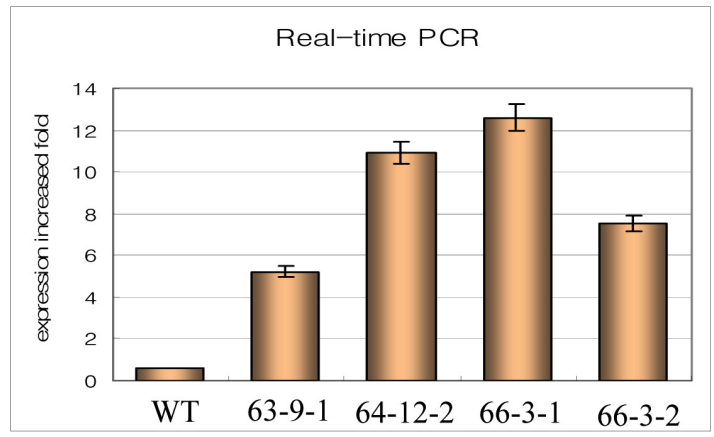

(C)

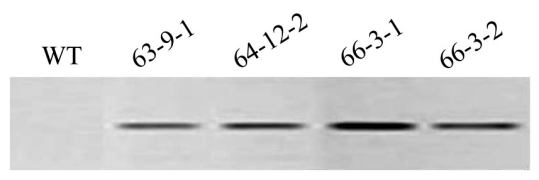

(D)

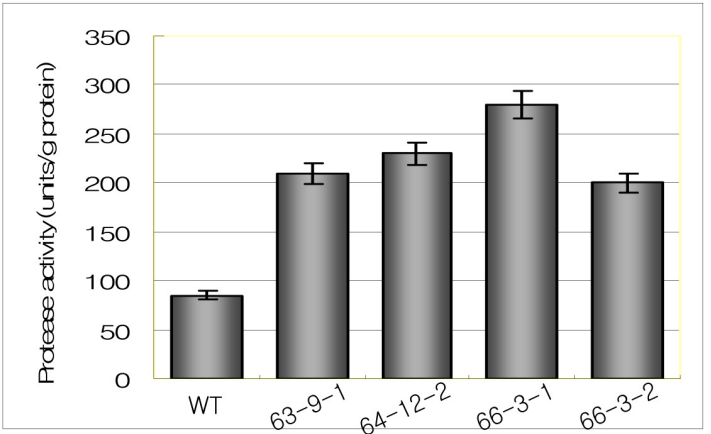

Fig. 2 Expression of BAA1 gene in transgenic plants. (A); The amplification products of the BAAl were separated using a 1.5\% Agarose gel. M: DNA-ladder; W: PCR generated from the cDNA template of the wild-type plant; P: PCR product generated from the cDNA template of the pIG $121 \mathrm{Hm}$ plasmid that contains the BAA1: 1 8, PCR products generated from the cDNA template of independent transgenic lines. (B); mRNA expression level using realtime PCR analysis. (C); Western blot analysis of BAA1 protein expression in Brassica rapa leaf tissue. Total soluble protein sample $(20 \mu \mathrm{g})$ from the wild type and two transgenic plants using an antimicrobial BAA polyclonal antibody. (D); Protease activity analysis

SPCP 3 (Chen et al. 2006) (Fig. 2B). In addition, the transgenic lines showed a 5- to 6-fold increase in endoprotease activity in leaves over the WT (Fig. 2C). Since the growth rate under normal conditions did not differ between the WT and transgenic lines, the above results show the actual increase of cysteine protease in the transgenic lines.
Transgenic lines exhibit enhanced soft rot disease resistance

Three transgenic lines (B63-9-1, B64-12-2 and B66-3-1) were selected based on high expression level of $B A A 1$ gene (Fig. 2A, C). When wild type and transgenic lines were inoculated with Pectobacterium carotovorum subsp. caro- 
(A)

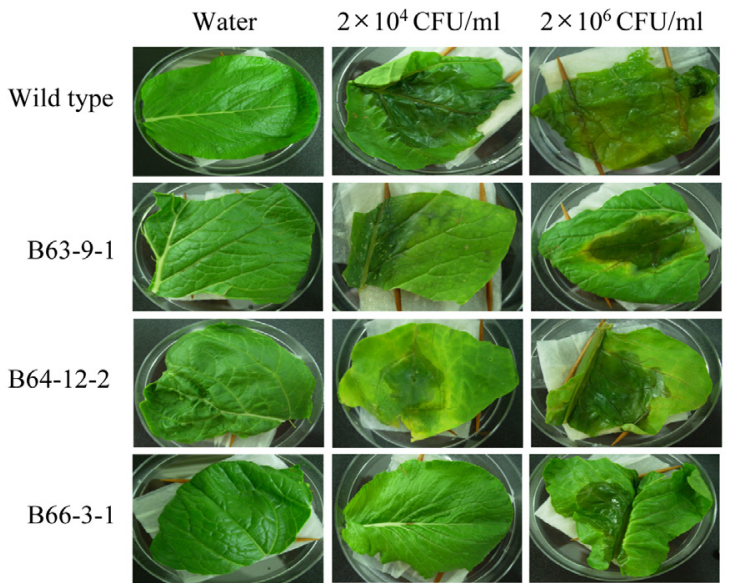

(B)

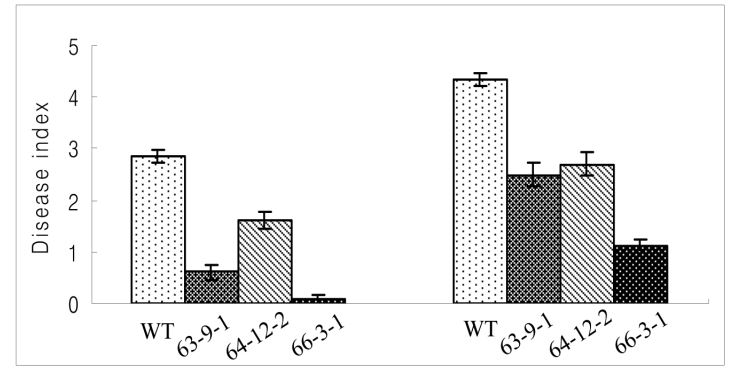

Fig. 3 Enhancing Bacterial Disease Resistance in Transgenic plants to 2days leaf after infection
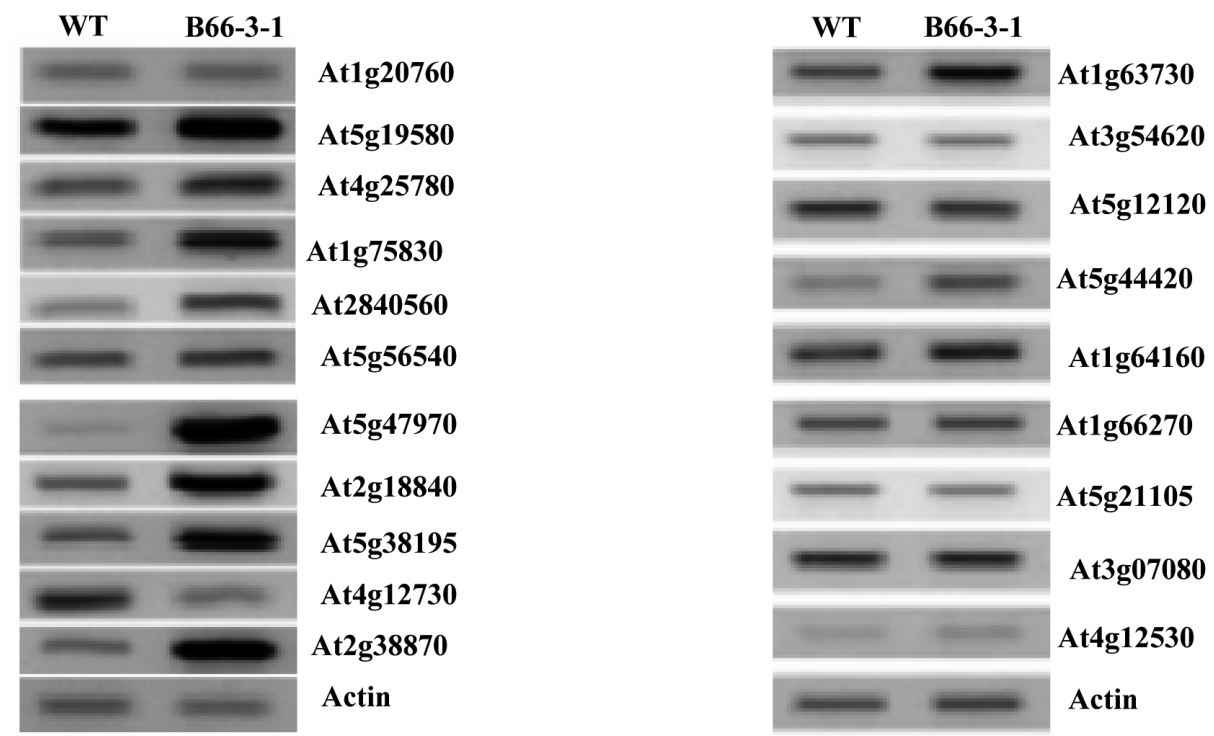

Fig. 4 Semi-quntitative RT-PCR analysis of expression levels of candidate genes identified by microarray analysis in B66-3-1 line and wild type control

tovorum, a disease index (DI) was calculated in $2 \times 10^{4}$ and $2 \times 10^{6} \mathrm{CFU}$ two days after inoculation. Upon infection with $2 \times 10^{4}$ CFU, B63-9-1 and 64-12-2 showed DI of 0.8 and 1.4, respectively, compared with 2.9 DI of WT, while B66-3-1 did not show disease symptoms (Fig. 3A, B). Upon infection with $2 \times 106 \mathrm{CFU}$, WT exhibited severe soft rot disease symptoms after two days, and died four days after infection, whereas transgenic lines showed much weaker symptoms as compared to WT (Fig. 3B).

Microarray analysis of transgenic line

In order to determine the global effects on BAA1 overexpression, mRNA transcription levels in leaves were compared between the WT and transgenic line (B66-3-1) by means of cDNA microarray analysis as described in Materials and Methods. Following data processing, several genes were shown to be consistently and significantly up- regulated, and others down-regulated in B66-3-1 as compared with WT. The filtering strategy selected changes on the basis of low $P$ value (less than 0.05 ), combined with the fold change in expression, for signals that were significantly greater than the background noise. The results showed that, of the 2,013 genes analyzed, 23 genes (1.14\% of total) were up-regulated and 11 genes down-regulated $(0.55 \%$ of total $)$ in the transgenics compared to the WT (Table 2). Interestingly, genes encoding defensin protein such as glyoxal oxidase, PR-1 protein, PDF1, protein kinase, LTP protein and UBA protein were up-regulated in the B66-3-1 line. Genes for cathepsin B-like protein, fatty acid desaturase family protein, tudor domain protein, thylakoidmembrane formation protein and helicase related protein were down- redulated in the B66-3-1 line. 
Table 2 Significantly up-regulated genes in the BAA1 transgenic B. rapa over the wild type counterpart using Arabidopsis $37 \mathrm{k}$ oligo chip

\begin{tabular}{|c|c|c|c|c|}
\hline \multirow{2}{*}{ Annotation } & \multirow{2}{*}{ Gene ID } & \multicolumn{3}{|c|}{ Expression levels } \\
\hline & & Transgenic $(\mathrm{T})$ & Wild type (W) & Ratio (T/W) \\
\hline Calcium-binding EF hand family protein & At1g20760 & 40627 & 3621 & 11.22 \\
\hline Putative protein & At4g33666 & 18144 & 1728 & 10.50 \\
\hline $\begin{array}{l}\text { Glyoxal oxidase precusor from Phanerochaete } \\
\text { chrysosporium }\end{array}$ & At5g19580 & 10020 & 1066 & 9.40 \\
\hline PR-1 protein from Medicago truncatula & At4g25780 & 35128 & 5816 & 6.04 \\
\hline Cystein-rich antifungal protein precursor (AFP1) & At1g75830 & 7432 & 1249 & 5.95 \\
\hline Protein kinase family protein & At2g40560 & 4638 & 876 & 5.35 \\
\hline Arabinogalactan-protein (AGP 14) & At5g56540 & 27891 & 5545 & 5.03 \\
\hline Nitrogen regulation family protein & At5g47970 & 17148 & 3672 & 4.67 \\
\hline Integral membrane Yip1 family protein & At2g18840 & 19970 & 4332 & 4.61 \\
\hline Protease inhibitor contains lipid transfer protein (LTP) & At5g38195 & 6781 & 1766 & 3.84 \\
\hline Fasciclin-like arabinogalactan-protein (FLA 2) & At4g12730 & 10052 & 2717 & 3.70 \\
\hline Protease inhibitor (BGIA) from Momordica charantia & At2g38870 & 29442 & 8412 & 3.50 \\
\hline Disease resistance protein (TIR-NBS-LRR class) & At1g63730 & 3406 & 973 & 3.50 \\
\hline BZIP transcription factor family protein & At3g54620 & 2142 & 619 & 3.46 \\
\hline Ubiquitin-associated (UBA)/TS-N domain protein & At5g12120 & 11635 & 3412 & 3.41 \\
\hline Unknown Protein & At5g06180 & 12975 & 3908 & 3.32 \\
\hline Plant defensin protein family & At5g44420 & 15566 & 4217 & 3.30 \\
\hline Disease resistance-responsive family protein & At1g64160 & 12899 & 4006 & 3.22 \\
\hline Beta-glycosidase (PSR 3. 2) & At1g66270 & 13121 & 4139 & 3.17 \\
\hline L-ascorbate oxidase from Nicotiana tabacum & At5g21105 & 5476 & 1755 & 3.12 \\
\hline Membrane protein contains Pfam & At3g07080 & 20826 & 6718 & 3.10 \\
\hline Protease inhibitor/seed storage/lipid transfer protein & At4g12530 & 7332 & 2365 & 3.10 \\
\hline DNA helicase (RECQ11) & At3g05740 & 5382 & 1794 & $3 . .00$ \\
\hline Non-race specific disease resistance protein & At3g20610 & 9289 & 3248 & 2.86 \\
\hline O-methyltransase & At5g53810 & 20028 & 7102 & 2.82 \\
\hline Mitochondrial import receptor subunit TOM7 & At5g41685 & 17702 & 6322 & 2.80 \\
\hline Auxin-responsive protein & At4g12980 & 11463 & 4230 & 2.71 \\
\hline Disease resistance-responsive protein & At2g21100 & 2612 & 997 & 2.62 \\
\hline Cellulose synthase & At5g44030 & 4167 & 1877 & 2.22 \\
\hline
\end{tabular}

The results of the microarray experiment were confirmed by semi-quantitative RT-PCR for a number of the most significant changes identified (Fig. 4). The expression pattern of this set of genes was also determined in B66-3-1 and compared to WT. The expression levels of AFP1 encoding cystein-rich antifungal protein, GDH encoding glutamate dehydrogenase, $\mathrm{PKC}$ encoding protein kinase and LTP encoding protease inhibitor increased in the B66-3-1 line as compared to WT. Whereas the genes encoding the amino acid transporter protein and nicotianamine synthase were decreased in the B66-3-1 line as compared to WT.

\section{Discussion}

Cysteine proteases are found in bacteria, eukaryotic microorganisms, animals and plants (Barrett 1986). Many cysteine proteases have been identified in plants, where they par- ticipate in diverse metabolic events of physiological importance. The $B A A 1$ gene encoding cysteine protease has been cloned from pineapple fruit (Muta et al. 1997). However there are no reports on the function of $B A A 1$ gene. In the present study, we developed transgenic Chinese cabbage by introducing the $B A A 1$ gene isolated from pineapple fruit, and monitored its functional analysis using molecular and biological approaches. Several transgenic lines with normal horticultural traits and development were generated from this work, and most of them carried a single copy of the transgene. The BAA1 transgenic Chinese cabbage lines showed variable levels of transgene expression at both the transcriptional and translational levels which did not correlate with transgene copy number. Our result provides the first evidence that it is possible to improve plant resistance by overexpression of gene encoding cysteine protease isolated from pineapple into Chinese cabbage. The 35S:BAA1 transgenic lines exhibited enhanced resistance to bacteria 
soft rot infection. This resistance was manifested in the clearly reduced ability of the bacteria to establish infection, suggesting that the early events in this interaction have been altered; important since many studies about enhanced diseaseresistance in transgenic cabbage plants have been reported (Hennin et al. 2001; Park et al. 2002; Cui et al. 2002; Wretblad et al. 2003). When infection and tissue maceration were initiated, however, the BAA1 protein appeared to be of less value because we could not observed any significant difference in bacterial growth between 35S:BAA1 transgenic and WT plants. However, when the soluble proteins (extraand intra-cellular) of BAA1-overexpressed yeast was added to the growth medium, the growth of the P. carotovorum ssp. was significantly inhibited during the early growth phase. Therefore, we can conclude that the BAA1 protein produced by the recombinant yeast cell has antimicrobial activity against $P$. carotovorum especially in the dilute conditions of the cell. The results support our hypothesis about the role of cysteine protease in pathogenicity, in which $P$. carotovorum subsp. carotovorum employs quorum sensing to avoid the premature production of plant cell wall degradation enzymes (PCWDEs) (Andres et al. 2001). The results from microarray analysis revealed the up-regulation of defensin protein such as glyoxal oxidase, PR-1 protein, PDF1, protein kinase, LTP protein and UBA protein in the transgenic B66-3-1 line over the WT (Table 2). These results support the view that introduction of transgene of $A$. comusus to target plants are capable of protecting plants from bacterial pathogen infection through the production of antibacterial genes or hypersensitivity cell death (HCD) associated genes (Keller et al. 1999; Shen et al. 2000; Verberne et al. 2000). Also, overexpression of R2R3 MYB-related gene or AtMYB30 leads to the induction of $\mathrm{HCD}$ and could resist pathogen attack (Vailleau et al. 2000). Similarly Ptil, a serine/ threonine kinase, overexpressed in tobacco accelerates the $\mathrm{HCD}$ and resists to infection of $P$. syringae pv. tabaci (Zhou et al. 1995). One of the most remarkable features in gene expression in our transgenic B66-3-1 line was the up-regulation of genes encoding arabinogalactan proteins (AGPs), fasciclinlike arabinogalactan proteins (FLAs). These AGP proteins regulate cell-cell interactions and communication, and provide key structural, positional and environmental signals during growth and development (Kim et al. 2003; Markus et al. 2006). Also the increased BAA1 expression could be an important factor responsible for the enhanced tolerance to multiple environmental stresses in our transgenic plants. WRKY transcription factors (Rizhsky et al. 2002; Kalde et al. 2003) and protein kinases (Saijo et al. 2000; Yoshida et al. 2002) have also been implicated in plant defense to environmental stresses. The possible contribution of up- regulation of genes encoding proteins associated with the enhanced stress tolerance in our transgenic Chinese cabbage requires further investigation.

\section{References}

Alonso JM, Granell A (1995) A putative vacuolar processing protease is regulated by ethylene and also during fruit ripening in Citrus fruit. Plant Physiol. 109:541-547

Andres M, Montesano M, Koiv V, Tapio-Palva E (2001) Transgenic plants producing the bacterial pheromone $\mathrm{N}$-acylhomoserine lactone exhibit enhanced resistance to the bacterial phytopathogen Erwinia carotovora. Mol. Plant-Microbe Interact. 14:1035-1042

Barrett AJ, Rawlings ND, Davies EM, Macheleidt M, Salvesen GE, Turk V (1986) In: Barrett, A. J. and Salvesen, G. E. eds. Proteinase inhibitors. Amsterdam Science Publishers 12: 515-569

Bradford MM (1976) A rapid and sensitive method for the quantitation of microgram quantities of protein utilizing the principle of protein dye binding. Anal. Biochem. 72:248-254

Buchanan-Wollaston V and Ainsworth C (1997) Leaf senescence in Brassica napus, cloning of senescence related genes by subtractive hybridization. Plant Mol. Biol. 33:821-843

Chen HJ, Huang DJ, Hou WC, Lui JH and Lin YH (2006) Molecular cloning and characterization of a granulin-containing cysteine protease SPCP 3 from sweet potato (Ipomoea batatas) senescent leaves. J. Plant Physiol. 163:863-876

Cui J, Jander G, Racki LR, Kim PD, Pierce NE and Ausubel FM (2002) Signals involved in Arabidopsis resistance to Trichoplussiani caterpillars induced by virulent and avirulent strains of the phytopathogen Pseudomonas syringae. Plant Physiol. 129:551-564

D' Silva I, Poirier GG and Heath MC (1998) Activation of cysteine proteases in cowpea plants during the hypersensitive responsea form of programmed cell death. Exp. Cell Res. 245:389-399

Eason JR, Ryan DJ, Pinkney TT and O'Donoghue EM (2002) Programmed cell death during flower senescence: isolation and characterization of cysteine proteinase from Sendersonia aurantiaca. Functional Plant Biol. 29:1055-1064

Gepstein S, Sabehi G, Carp M J, Hajouj T, Nesher MFO, Yariv I, Dor C and Bassani M (2003) Large-scale identification of leaf senescence-associated genes. The Plant J. 36:629-642

Granell A, Cercos M, Carbonell J (1988) Plant cysteine proteinases in germination and senescence. In: Barrett, A. J., Rawlings, D. D. and Woessner, J. F. eds. The handbook of proteolytic enzymes. San Diego: Academic Press, 578-583

Guerrero C, Calle M, Reid MS, Valpuesta V (1998) Analysis of the expression of two thiolprotease genes from daylily (Hemero callis spp) during flower senescence. Plant Mol. Biol. 36: 565-571

Harrak H, Azelmat S, Baker EN, Tabaeizadeh Z (2001) Isolation and characterization of gene encoding a drought-induced cysteine protease in tomato (Lycopersicon esculentum). Genome 
44:368-374

He YK (1990) Plant regeneration from Ri T-DNA transformed roots of cabbage. Chin J. Biotechnol. 6:131-137

Hennin C, Hofte M, Diederichsen E (2001) Functional expression of Cf9 and Avr9 genes in Brassica napus induces enhanced resistance to Leptosphaeria maculans. Mol. Plant Microbe Interact. 14:1075-1085

Holwerda BC, Rogers JC (1992) Purification and characterization of aleurain. Plant Physiol. 99:848-855

Hughes TR, Mao M, Jones AR, Burchard J, Linsley PS (2001) Expression profiling using microarrays fabricated by an ink-jet oligonucleotide synthesizer. Nat. Biotechnol. 19:342-347

Kalde M, Barth M, Somssich IE, Lippok B (2003) Members of the Arabidopsis WRKY group III transcription factors are part of different plant defence signaling pathways. Mol. Plant Microbe Interact. 16:295-305

Kardailsky IV, Brevin NJ (1996) Expression of cysteine protease genes in pea nodules development and sencescene. Mol. Plant-Microbe Interact. 9:689-695

Keller H, Pamboukdjian N, Ponchet M, Poupet A, Delon R, Verrier JL, Roby D, Ricci P (1999) Pathogen-induced elicitin production in transgenic tobacco generates a hypersensitivity response and nonspecific disease resistance. Plant Cell 11:223-235

Kim LJ, Brian JJ, Antony B, Carolyn JS (2003) The fasciclin-like arabinoglactan proteins of Arabidopsis. A multigene family of putative cell adhesion molecules. Plant Physiol. 133:19111925

Koizumi M, Yamaguchi-Shinozaki K, Tsuji H, Shinozaki K (1993) Structure and expression of two genes that encode distinct drought-inducible cysteine proteinase in Arabidopsis thaliana. Gene 29:175-182

Laemmli NK (1970) Cleavage of structural proteins during the assembly of the head of bacteriophage T4. Nature 227:680685

Ling J, Kojima T, Shiraiwa M, Takahara H (2003) Cloning of two cysteine proteinase genes: $C y s P 1$ and $C y s P 2$, from soybean cotyledons by cDNA representational difference analysis. Biochimica et Biophysica Acta 1627:129-139

Linthorst HJM, Vanderdoes C, Brederode FT, Bol JF (1993) Circadian expression and induction by wounding of tobacco genes for cysteine proteinase. Plant Mol. Biol. 21:685-694

Lohman KN, Gan S, John MC, Amasino RM (1994) Molecular analysis of natural leaf senescence in Arabidopsis thaliana. Physiologia Plantarum 92:322-328

Markus A, Belastegui-Macadam X, Kaldenhoff R (2006) An attack of the plant parasite Cuscuta reflexa induces the expression of attAGP, an attachment protein of the host tomato. The Plant J. 48:548-556

Murashige T, Skoog E (1962) A revised medium for rapid growth and bioassays with tobacco tissue cultures. Physiol. Plant 15: 473-497

Muta E, Okamoto Y, Ota S (1997) Cloning and sequencing of cysteine proteinase in Ananas comosus. Accession No. GI2351106 from NCBI database

Naito Y, Fujie M, Usami S, Murooka Y, Yamada T (2000) The involvement of cysteine proteinase in the nodule development in Chinese milk vetch infected with Mesorhizobium huakuii subsp. Rengei. Plant Physiol. 124:1087-1096

Okamoto T, Shimada T, Hara-Nishimura I, Nishimura M, Minamikawa T (2003) C-terminal KDEL sequence of a KDEL-tailed cysteine proteinase (sulfhydryl-endopeptidase) is involved in formation of KDEL vesicle and in efficient vacuolar transport of sulfhydryl-endopeptidase. Plant Physiol. 132:1892-1900

Park HC, Kang YH, Chun HJ, Koo JC, Cheong YH, Kim CY, Kim MC, Chung WS, Kim JC, Yoo JH, Koo YD, Koo SC, Lim CO, Lee SY, Cho MJ (2002) Characterization of a stamen-specific cDNA encoding a novel plant defensin in Chinese cabbage. Plant Mol. Biol. 50:59-69

Ren J, Petzoldt R, Dickson MH (2001) Screening and identification of resistance to bacterial soft rot in Brassica rapa. Euphytica 118:271-280

Rizhsky L, Liang H, Mittler R (2002) The combined effect of drought and heat shock on gene expression in tobacco. Plant Physiol. 130:1143-1151

Saijo Y, Hata S, Kyozuka J, Shimanoto K, Izui K (2000) Overexpression of a single $\mathrm{Ca}^{+2}$ dependent protein kinase confers both cold and salt/ drought tolerance on rice plants. Plant J. 23:319-327

Schaffer MA, Fischer RL (1988) Analysis of mRNAs that accumulates in response to low temperature identifies a thiolprotease gene in tomato. Plant Physiol. 87:431-436

Schmid M, Simpson D, Gietl C (1999) Programmed cell death in castor bean endosperm is associated with the accumulation and release of a cysteine endopeptidase from ricinosomes. Proceedings of the National Academy of Sciences, USA 96: 14159-14164

Schmid M, Simpson D, Sarioglu H, Lottspeich F, Gietl C (2001) The ricinosomes of senescing plant tissue bud from the endoplasmic reticulum. Proceedings of the National Academy of Sciences, USA 98:5353-5435

Shen S, Li Q, He SY, Barker KR., Li D, Hunt AG (2000) Conversion of compatible plant-pathogen interactions into incompatible interactions by expression of the Pseudomonas syringae pv. syringae $61 \mathrm{hrmA}$ gene in transgenic tobacco plants. Plant J. 23:205-213

Shimada T, Hiraiwa N, Nishimura M, Hara-Nishimura I (1994) Vacuolar processing enzyme of soybean that converts proproteins to the corresponding mature forms. Plant and Cell Physiol. 35:713-718

Solomon M, Belenghi B, Delledonne M, Menachem E, Levine A. (1999) The involvement of cysteine proteases and protease inhibitor genes in the regulation of programmed cell death in plants. The Plant Cell 11:431-444

Toyooka K, Okamoto T, Minamikawa T (2000) Mass transport of a proform of a KDEL-tailed cysteine proteinase (SH-EP) to protein storage vacuoles by endoplasmic reticulum-derived vesicle is involved in protein mobilization in germinating seeds. J. of Cell Biol. 148:453-563

Ueda T, Seo S, Ohashi Y, Hashimoto J (2000) Circadian and senescence-enhanced expression of a tobacco cysteine protease 
gene. Plant Mol. Biol. 44:649-657

Verberne MC, Verpoorte R, Bol JF, Mercado-Blanco J, Linthorst HJM (2000) Overproduction of salicylic acid in plants by bacterial transgenes enhances pathogen resistance. Nat. Biotechnol. 18:779-783

Wretblad S, Bohman S, Dixelius C (2003) Overexpression of a Brassica nigra cDNA gives enhanced resistance to Leptosphaeria maculans in B. napus. Mol. Plant Microbe Interact. 16:477-484

Xu XF, Chye LM. (1999) Expression of cysteine proteinase during developmental events associated with programmed cell death in brinjal. The Plant J. 17:321-328

Yoshida R, Hobo T, Ichimura K, Mizoguchi T, Takahashi F, Aronso J, Ecker JR, Shinozaki K (2002) ABA-activated SnRK2 protein kinase is required for dehydration stress signaling in Arabidopsis. Plant Cell Physiol. 43:1473-1483

Zhou J, Loh YT, Bressan RA, Martin GB (1995) The tomato gene ptil encodes a serine/threonine kinase that is phosporylated by Pto and is involved in the hypersensitive response. Cell 15: 925-935 